\title{
A New Concept in Promoting Tourism: Thematic Evenings
}

\author{
Assist. Prof. Simona BADER, PhD \\ Department of Communication Sciences \\ Faculty of Political Sciences, Philosophy and Communication Sciences \\ West University Timişoara \\ E-mail: simona.bader@e-uvt.ro
}

\begin{abstract}
In every field, especially services the market is in a permanent evolution and those engaged must find new modalities to make their services known as efficient and appealing as possible. Such a field is tourism and the communication strategies of travel agencies follow in Romania the classical modalities: online and offline media, fairs and exhibitions by which companies try to face the increasing concurrency. The purpose of this paper is to present and make an analysis of a communication strategy which is less used in tourism, conceptual events named Thematic Evenings (TE). TE consists in a serial of conceptual events having as main item location for possible cultural, gastronomic or recreational tourism. This paper is a retrospective study on a number of 15 events which took place during two years being designed in order to facilitate and spread specific cultural and touristic values from different countries, cities or parts of the world. I made an analysis of outcomes on medium and long term reflected in direct or media feed-back from customers. Results and discussion of TE are detailed in the text and can be appreciated as positive for both the image of company and as a PR campaign.
\end{abstract}

Keywords: conceptual events; thematic evenings; public relation; tourism; communication. 


\section{References}

1. Dagenais, B. (2003). Campania de relații publice, [Public Relation campaign], Iași, Polirom.

2. Dagenais, B. (2002). Profesia de relaționist, [PR Profession], Iași, Editura Polirom.

3. Huertas, A. (2008). Public relations and tourism: Fighting for the role of public relations in tourism, Retrieved May 6, 2016, from https://www.researchgate.net/publication/ 248528018_Public_relations_and_tourism_Fighting_for_the_role_of_public_rela tions_in_tourism.

4. MacCannel, Dean (1999). The tourist: a new theory of the leisure class, University of California Press, Berkeley.

5. Minciu, R. (2000). Economia turismului. Bucureşti, Editura Uranus.

6. Petrovici, A. (2014). Public Relations in Tourism. A Research on The Perception of The Romanian Public Upon Responsible Tourism. Retrieved May 6, 2017, from http://www.sciencedirect.com/science/article/pii/S1877042814063885.

7. Sharpley, R., \& Stone, S.P. (2010, October 4). Tourist Experience.Contemporary Perspectives. Retrieved November 29, 2016, from https://books.google.ro/books.

8. Sniadek, J. (2006). Age of Seniors - A Challenge for Tourism and Leisure Industry. Studies in Physical Culture and Tourism, Vol. 13, Supplement. Retrieved February 5, 2017.

9. Urry, John (2002). The Tourist Gaze. Sage Publication. 